\title{
ANALISIS HUBUNGAN FAKTOR RISIKO DENGAN KEJADIAN INTERAKSI OBAT POTENSIAL PASIEN GERIATRI DI RUMAH SAKIT SWASTA YOGYAKARTA
}

\author{
Maya Arfania \\ Program Studi Farmasi Universitas Buana Perjuangan Karawang \\ maya.arfania@ubpkarawang.ac.id
}

\begin{abstract}
Abstrak
Dewasa ini populasi di Indonesia meningkat dengan pesat. Diprediksi Indonesia akan menduduki 10 besar tertinggi yang memiliki populasi berusia lebih dari 60 tahun, yaitu sebesar 54 per 1000 orang pada tahun 1980 dan 76 per 1000 orang pada tahun 2000. Kemungkinan proporsi lanjut usia akan mencapai 9,8\% dari total populasi pada tahun 2010, bahkan peningkatannya dapat mencapai 3,7\% antara tahun 2010 sampai 2020.
\end{abstract}

Penelitian ini adalah penelitian cross sectional, dimana pengambilan sampel dilakukan secara purposive random sampling. Jumlah sampel yang digunakan adalah sebesar 100 lembar resep. Setelah dilakukan analisis dengan menggunakan chi square diketahui bahwa dalam peneltiian ini, jenis kelamin dan jumlah obat bukanlah menjadi faktor risiko dari potensi terjadinya interaksi obat.

Kata kunci : geriatri, interaksi obat, penyakit kronis

\begin{abstract}
The population in Indonesia was increase rapidly nowadays. It is been predicted Indonesia will occupy the highest top 10 who has population over 60 years, wich is equal to 54 per 1000 people in 1980 and 76 per 1000 people in 2000. It's possible that the proportion of elderly will reach 9,8\% of total population in 2010, even the increase can reach 3,7\% between 2010 and 2020.

This study was a cross-sectional study, where the sampling was done by purposive random sampling. The number of samples is 100 recipes. After analyzed usig chi square, it was found that in this study, gender and the number of drugs were not the risk factor of potential drug interactions.
\end{abstract}

Keywords: geriatri, drug interaction, chronic disease

\section{PENDAHULUAN}

Dewasa ini populasi di Indonesia meningkat dengan pesat. Diprediksi Indonesia akan menduduki 10 besar tertinggi yang memiliki populasi berusia lebih dari 60 tahun, yaitu sebesar 54 per 1000 orang pada tahun 1980 dan 76 per 1000 orang pada tahun 2000 . Kemungkinan proporsi lanjut usia akan mencapai 9,8\% dari total populasi pada tahun 2010, bahkan peningkatannya dapat mencapai 3,7\% antara tahun 2010 sampai 2020 (Lea, 2001).

Pada geriatri (60 tahun ke atas) terjadi penurunan fungsi organ vital, sehingga memungkinkan untuk timbulnya penyakit yang bersifat multipatologik dan kronis (Martono, 2009). Semakin banyak penyakit yang diderita, semakin banyak pula obat yang diterima. Banyaknya jumlah obat-obatan yang dikonsumsi dapat meningkatkan risiko gangguan kesehatan dan berpotansi untuk mengalami polifarmasi. Kejadian polifarmasi dapat meningkatkan terjadinya interaksi obat (Fulton, 2005).

Terdapat penelitian epidemiologi yang menyatakan bahwa pasien rawat inap mengalami kejadian interaksi obat hingga $30 \%$ dan pada pasien rawat jalan sebesar 70,3\% (Filho, 2006). Hal serupa sejalan dengan penelitian yang dilakukan di Mexico, dimana 
dari 624 pasien geriatri yang berobat rawat jalan mendapatkan resep dengan interaksi obat sebesar $80 \%$ pasien (Doubova et al, 2007). Penelitian yang dilakukan oleh Netto (2012) yang melibatkan 433 pasien geriatri di Brazil menunjukkan sebesar 6,5\% pasien memiliki risiko untuk mengalami interaksi obat.

Berdasarkan kejadian-kejadian mengenai interaksi potensial pada pasien geriatri diatas, maka peneliti tertarik untuk melakukan penelitian mengenai analisis faktor risiko interaksi obat potensial pada pasien geriatri di RS Swasta Yogyakarta.

\section{METODE PENELITIAN}

Penelitian ini adalah penelitian cross sectional yang dilakukan pada pasien geriatri di Rumah Sakit swasta Yogyakarta. Jumlah sampel dalam penelitian ini adalah sebesar 100 lembar resep, dimana pengambilan sampel dilakukan secara purposive random sampling.

Seratus lembar resep dianalisa interaksi obat potensial dengan menggunakan software Drug in Fact. Setelah itu, dianalisis faktor risiko dengan menggunakan chi square. Faktor risiko yang dianalisis adalah jenis kelamin dan jumlah obat.

\section{HASIL dan PEMBAHASAN}

Lembar resep yang digunakan dalam penelitian adalah lembar resep pasien geriatri yang didalamnya terdapat obat-obat yang diperuntukkan penyakit kronis. Resep yang diambil adalah sebanyak 100 lembar. Tabel 1 menunjukkan karakteristik pasien geriatri, dimana jumlah pasien laki-laki dan perempuan masing-masing sebanyak $50 \%$.

Tabel 1. Karakteristik Pasien Geriatri

\begin{tabular}{lcc}
\hline \multicolumn{1}{c}{ Variabel } & $\mathrm{n}$ & $\%$ \\
\hline Jenis Kelamin: & & \\
Laki-laki & 50 & 50 \\
Perempuan & 50 & 50 \\
Jumlah Diagnosis: & & 23 \\
1 Diagnosis & 23 & 51 \\
2 Diagnosis & 51 & 20 \\
3 Diagnosis & 20 & 4 \\
4 Diagnosis & 4 & 2 \\
5 Diagnosis & 2 & 52 \\
Jumlah Obat: & & 48 \\
<5 & 52 & \\
Kejadian Interaksi Obat: & 48 & 27 \\
Interaksi Obat & & 73 \\
Tidak Interaksi Obat & 27 & \\
\hline
\end{tabular}

Dari 50 pasien geriatri laki-laki, terdapat 5 pasien (10\%) yang berpotensi untuk mengalami interaksi obat. Sedangkan dari 50 pasien geriatri perempuan, terdapat 12 pasien $(24 \%)$ yang mengalami interaksi obat. Pada penelitian ini, jumlah obat bervariasi dalam tiap lembar resepnya. Pada lembar resep dengan jumlah obat $<5$, terdapat $52 \%$ yang berpotensi mengalami interaksi obat. Sedangkan pada lembar resep dengan jumlah obat $\geq 5$ obat, terdapat $48 \%$ yang berpotensi berinteraksi. 
Terdapat beberapa faktor risiko yang dapat menyebabkan terjadinya interaksi obat, salah satunya adalah polifarmasi. Polifarmasi yang dimaksud ddalam peneltian ini adalah lembar resep dengan $\geq 5$ jenis obat. (Varallo et al, 2006). Dalam penelitian ini faktor risiko yang dianalisis adalah jenis kelamin dan polifarmasi. Analisi faktor risiko dilakukan dengan menggunakan chi square, dimana didapatkan hasil jenis kelamin dan jumlah obat tidak berhubungan dengan risiko terjadinya interaksi obat dengan nilai $p$ masing-masing adalah sebesar 0,06 dan 0,13.

\section{KESIMPULAN}

Setelah dilakukan analisis dengan menggunakan chi square diketahui bahwa dalam peneltiian ini, jenis kelamin dan jumlah obat bukanlah menjadi faktor risiko dari potensi terjadinya interaksi obat.

\section{DAFTAR PUSTAKA}

Doubova et al. 2007. Potential drug-drug and drug disease interactions in prescriptions for ambulatory patients over 50 years of age in family medicine clinics in Mexico city. BMC Health Services Research. 7(147).

Fulton MM, Allen ER. 2005. Polypharmacy in elderly: literature review. J Am Acad Nurse Prac. 17(4): 123-32).

Filho et al. 2006. Effect of Bethametasone and Diclofenac Sodium on Serum and Tissue Concentration af Amoxicillin in vivo study in rats. J Appl Oral Sci. 14(5): 319-23.

Lee A. 2001. Drug-drug interactions. UK: John Wiley \& Son LTD. 211.

Martono. 2009. Pelayanan Kesehatan Pada Usia Lanjut. Jakarta: Balai Penerbit FKUI. Ed 4: $772-776$

Varallo, FR., et al. 2014. Possible adverse drug events leading to hospital admission in a Brazillian teaching hospital. Clinics 69. 163-167. 